\title{
Molecular Regulatory Networks for Improving Nitrogen Use Efficiency in Rice
}

\author{
Mengmeng Hou ${ }^{1,2}$, Ming $\mathrm{Yu}^{2}$, Zhiqiang $\mathrm{Li}^{2,3,4}$, Zhiyuan $\mathrm{Ai}^{5}$ and Jingguang Chen ${ }^{1, *}$ \\ 1 School of Agriculture, Sun Yat-sen University, Guangzhou 510275, China \\ 2 Shenzhen Branch, Guangdong Laboratory of Lingnan Modern Agriculture, Genome Analysis Laboratory of \\ the Ministry of Agriculture and Rural Affairs, Agricultural Genomics Institute at Shenzhen, Chinese \\ Academy of Agricultural Sciences, Shenzhen 518120, China; houmengmeng@caas.cn (M.H.); \\ yuming@caas.cn (M.Y.); $104753200991 @ v i p . h e n u . e d u . c n(Z . L$. \\ 3 State Key Laboratory of Crop Stress Adaptation and Improvement, School of Life Sciences, Henan University, \\ Kaifeng 475004, China \\ 4 Shenzhen Research Institute of Henan University, Shenzhen 518000, China \\ 5 State Key Laboratory for Conservation and Utilization of Subtropical Agro-Bioresources, College of Life \\ Science and Technology, Guangxi University, Nanning 530004, China; 2008301001@st.gxu.edu.cn \\ * Correspondence: chenjg28@mail.sysu.edu.cn
}

Citation: Hou, M.; Yu, M.; Li, Z.; Ai, Z.; Chen, J. Molecular Regulatory Networks for Improving Nitrogen Use Efficiency in Rice. Int. J. Mol. Sci. 2021, 22, 9040. https://doi.org/ $10.3390 /$ ijms 22169040

Academic Editor: Ki-Hong Jung

Received: 22 July 2021

Accepted: 17 August 2021

Published: 21 August 2021

Publisher's Note: MDPI stays neutral with regard to jurisdictional claims in published maps and institutional affiliations.

Copyright: (c) 2021 by the authors. Licensee MDPI, Basel, Switzerland. This article is an open access article distributed under the terms and conditions of the Creative Commons Attribution (CC BY) license (https:// creativecommons.org/licenses/by/ $4.0 /)$.

\begin{abstract}
Nitrogen is an important factor limiting the growth and yield of rice. However, the excessive application of nitrogen will lead to water eutrophication and economic costs. To create rice varieties with high nitrogen use efficiency (NUE) has always been an arduous task in rice breeding. The processes for improving NUE include nitrogen uptake, nitrogen transport from root to shoot, nitrogen assimilation, and nitrogen redistribution, with each step being indispensable to the improvement of NUE. Here, we summarize the effects of absorption, transport, and metabolism of nitrate, ammonium, and amino acids on NUE, as well as the role of hormones in improving rice NUE. Our discussion provide insight for further research in the future.
\end{abstract}

Keywords: nitrogen use efficiency (NUE); absorption and transport; assimilation; nitrate; ammonium; transporter; quantitative trait locus (QTL); hormone; rice (Oryza sativa L.)

\section{Introduction}

Rice is the staple food for more than half of the world's population. Nitrogen is the most abundant mineral element in plants and the main limiting factor in rice production. The application of nitrogen fertilizer has greatly increased global crop yield, accompanied by increasingly severe economic and environmental costs [1]. Therefore, it is urgent to understand the molecular regulation mechanism of nitrogen absorption and utilization in rice and formulate strategies to improve nitrogen use efficiency (NUE). NUE is the guarantee of high yield and quality of rice. With the rapid development of agriculture in China, the input of nitrogen fertilizer has reached significant scale, and some new varieties of rice have demonstrated a problematically low utilization efficiency of fertilizer [1,2]. Today, China is the largest fertilizer consumer in the world, with the production and application of nitrogen fertilizer accounting for more than one third of global total (IFA annual report, 2015). According to statistics, from 1980 to 2013, the net amount of agricultural nitrogen fertilizer application increased by nearly 1.6 times. However, the total grain yield only increased by $87 \%$, the seasonal (traditional) NUE of main crops was only about $35 \%$, and the nitrogen efficiency (including soil residual fertilizer nitrogen) was only about $48 \%$, which was significantly lower than the international average [2,3]. Excessive application of nitrogen fertilizer results in energy waste, higher costs, soil acidification, water eutrophication and greenhouse gas emissions, which seriously restricted the sustainable development of agricultural production [1,4]. Besides, in the pursuit of high yield, how to fully explore the genetic potential of nitrogen absorption and utilization in rice, to reduce the demand 
for nitrogen from breeding and improve NUE, remains a crucial scientific problem in crop molecular design breeding.

\section{Genetic Variation in NUE among Various Rice Germplasm}

There are significant genetic and environmental differences in nitrogen uptake and utilization in rice. Currently, cultivated rice is mainly divided into two subspecies, Indica and Japonica [5]. Japonica is suitable for high-altitude areas with mild climate, with strong cold and fertilizer tolerance, while Indica is suitable for tropical and subtropical areas with high temperature, strong light and humidity, with weak cold and fertilizer tolerance. Compared with Japonica rice, Indica had higher nitrate uptake and utilization efficiency and overall NUE [6-9]. In addition, there were significant differences in NUE among local varieties, conventional rice, and hybrid rice, as well as among different varieties or lines within the same subspecies. The study [10] has shown that average nitrogen uptake and utilization efficiency of Indica rice was $14.1 \%$ higher than Japonica, and hybrid rice was higher than that of conventional rice. Among them, hybrid Indica rice is $22.8 \%$ higher than conventional Indica rice, and hybrid Japonica rice is $16.4 \%$ higher than conventional Japonica rice [9]. The genetic diversity of rice nitrogen use efficiency also provides a theoretical basis for the breeding and improvement of NUE in rice varieties.

Based on the significant genetic differences in nitrogen use efficiency among rice germplasm, researchers have used different germplasm resources to construct genetic populations, screening and identifying several QTLs related to nitrogen use efficiency in recent years. qNUEP- 6 was identified to function in NUE through the recombinant inbred line (RIL) population constructed by Zhenshan 97 and Minghui 63 [11]. Multiple QTLs related to NUE were subsequently identified by using various RIL and chromosome segment substitution line (CSSL) populations [3,12]. In addition, several QTLs related to low nitrogen tolerance were identified in different genetic populations [13,14]. A total of 110 early rice varieties collected from 52 countries (regions) in different geographical regions of the world were comprehensively identified for agronomic traits. It was found that there was a high correlation between tillering nitrogen response ability and NUE variation in many agronomic traits under different nitrogen fertilizer conditions. A variant of OsTCP19 promoter was identified by genome-wide association analysis (GWAS). Further study found OsTCP19 regulated nitrogen uptake by regulating the expression of nitrogen utilization genes to meet the demand of nitrogen growth [2]. A similar situation occurs in the promoter of OsARE. After analyzing 2155 rice varieties, we found that $18 \%$ of Indica and $48 \%$ of Japonica had small insertion in ARE1 promoter, which led to the decrease of ARE1 expression, caused delayed senescence, and resulted in $10-20 \%$ grain yield increases under limited nitrogen condition [15].

\section{Nitrate Relative Genes Play an Important Role in Improving NUE in Rice}

Plants mainly absorb nitrogen from soil in two inorganic forms, nitrate and ammonium. Given the anaerobicity of paddy soil, it is generally believed that ammonium is the main form of nitrogen in rice. However, rice has developed aerenchyma, which can transport oxygen from the ground to the roots and release it into the rhizosphere microenvironment, leaving the rhizosphere soil in a certain oxidation state, thus enhancing the nitrification of soil bacteria to convert ammonium into nitrate, and converting $15-40 \%$ of nitrogen into nitrate [16]. A large number of experiments at home and abroad have shown that, compared with single ammonium nitrogen supply, partially nitrate nitrogen can significantly promote the nitrogen absorption and utilization efficiency of rice [17-20]. Therefore, the uptake and assimilation of nitrate has become an important factor affecting NUE in rice.

In recent years, nitrate transporter genes as a famous family have been used in crop breeding to improve NUE $[6,19,21-26]$. LeNRT2.3 mediates the low affinity nitrate transport system in tomato. Overexpression of LeNRT2.3 can increase the uptake of $\mathrm{NO}_{3}{ }^{-}$in tomato roots and the transport of $\mathrm{NO}_{3}{ }^{-}$from root to shoot, thus increasing the biomass and 
fruit weight [27]. Tanrt2.1 can increase the uptake of $\mathrm{NO}_{3}{ }^{-}$in wheat after flowering [28]. TaNAC2-5a is a key transcription factor controlling the expression of nitrate transporter. Overexpression of TaNAC2-5a can increase wheat growth, grain yield and nitrogen harvest index [21]. Overexpression of NAC2 gene in wheat can increase the expression of TaNRT2.1 and TaGS2 [21].

The absorption and utilization of $\mathrm{NO}_{3}{ }^{-}$in rice is a complex process, including absorption, translocation and assimilation. In order to adapt to the changing environment, plants have evolved two nitrate transport systems, low affinity transport systems (LATS) and high affinity transport systems (HATS), which are responsible for NRT1/PTR (NPF) family members and NRT2 family members respectively. The NRT2 family in rice includes OsNRT2.1, OsNRT2.2, OsNRT2.3a, OsNRT2.3b, and OsNRT2.4 [20,23-25,29-33]. OsNRT2.1, OsNRT2.2, and OsNRT2.3a need to interact with OsNAR2.1 protein to have $\mathrm{NO}_{3}{ }^{-}$transport activity $[29,33]$. OsNRT2.3a was involved in the transport of $\mathrm{NO}_{3}{ }^{-}$from root to shoot [34]. A subsequent study found that OsNRT2.3b did not need the interaction of OsNAR2.1 and could transport $\mathrm{NO}_{3}{ }^{-}$alone [30]. Overexpression of OsNRT2.3b increased the buffering capacity of cell $\mathrm{pH}$ and significantly improved the grain yield and NUE of rice $[19,26]$ (Figure 1). Our previous results showed that the expression of $p$ OsNAR2.1:OsNAR2.1 could increase the $\mathrm{NO}_{3}{ }^{-}$uptake rate at seedling stage, significantly promote rice growth, and improve grain yield and agronomic NUE [22]. The expression of $p$ OsNAR2.1:OsNRT2.1 increased the expression ratio of OsNRT2.1 to OsNAR2.1 in stem, and increased grain yield and NUE in rice [25]. Co-overexpression of OsNAR2.1 and OsNRT2.3a can improve the biomass and nitrate transport efficiency, and ultimately improve the grain yield and NUE in rice [23]. A putative nitrate transporter gene OsNPF4.5 was induced by mycorrhizal, which is exclusively expressed in the cells containing arbuscules and displayed a low-affinity $\mathrm{NO}_{3}{ }^{-}$transport activity involved in symbiotic $\mathrm{N}$ uptake [35].

Chlorate is a kind of nitrate analogue, which was in the same pathway as $\mathrm{NO}_{3}{ }^{-}$ absorption and assimilation in plants. Therefore, chlorate sensitivity simulated nitrate uptake or assimilation in rice. Hu et al. [6] used $\mathrm{BC}_{2} \mathrm{~F}_{5}$ lines derived from the cross between IR24 and Nipponbare were screened for chlorate sensitivity, and the chromosome segment substitution line (CSSL) with the highest chlorate sensitivity was used for fine mapping. The nitrate transporter gene OsNRT1.1b was cloned from Indica, and then OsNRT1.1b-Indica was introduced into Japonica rice varieties, which could significantly improve the yield and NUE of Japonica rice. OsNRT1.1b can also interact with phosphate signal repressor OsSPX4, which in turn activates phosphate and nitrate response genes to achieve coordinated utilization of nitrogen and phosphorus [36]. Gao et al. [8] used RIL populations of 9311 and Nipponbare to detect a QTL for potassium chlorate resistance, $q C R 2$. After fine mapping and cloning, it was found that it encodes a NAD (P) H-dependent nitrate reductase gene OsNR2, and the difference between arginine (Indica) and tryptophan (Japonica) in the NAD ( $\mathrm{P}) \mathrm{H}$ binding domain is the determinant of the enzyme activity difference between the two OsNR2 genes. OsNR2 also interacts with OsNRT1.1b in a positive feedback manner. In Japonica, aggregating these two genes from Indica can obtain higher yield and NUE than a single gene [8]. OsNPF6.1 was cloned through GWAS analysis based on three-year field experiment, whereby it was found that the excellent haplotype of OsNPF6.1 could enhance nitrogen absorption and NUE, thereby improving rice yield under low nitrogen, and OsNAC42 can activate the expression of OsNPF6.1 [37]. OsNPF2.2 is a low-affinity nitrate transporter and participate in unloading nitrate from the xylem [38], OsNPF2.4 functions in acquisition and long-distance transport of $\mathrm{NO}_{3}{ }^{-}$[39]. Modified expression of OsNPF7.1, OsNPF7.2, OsNPF7.3, OsNPF7.4, and OsNPF7.7 differentially regulates tillering and grain yield in rice [40-43]. A NIN-like protein OsNLP4 was identified to function in NUE. Loss of OsNLP4 dramatically reduced yield and NUE compared with wild type under different $\mathrm{N}$ regimes. In contrast, the OsNLP4 overexpression lines increased yield and NUE under moderate N levels compared with wild type. Transcriptomic analyses revealed that OsNLP4 orchestrates the expression of a majority of known $\mathrm{N}$ uptake, assimilation, and signalling genes by directly binding to the nitrate-responsive cis-element in their promoters to regulate 
their expression. Moreover, overexpression of OsNLP4 can rescue the phenotype of atnlp7 mutant and enhance its biomass [44]. Interestingly, the same results were found through GWAS analysis. OsNLP4 transactivated OsNiR encoding nitrite reductase that was critical in nitrogen assimilation in rice. Using constructed quadrupling NREs (Nitrate-responsive cis-elements) in the promoter of OsNiR ( $p 4 x N R E: O s N i R$ ) enhanced nitrogen assimilation significantly. OsNLP4-OsNiR increased tiller number and yield through enhancing nitrogen assimilation and NUE [45]. The nitrate related genes involved in NUE are summarized in Table 1.

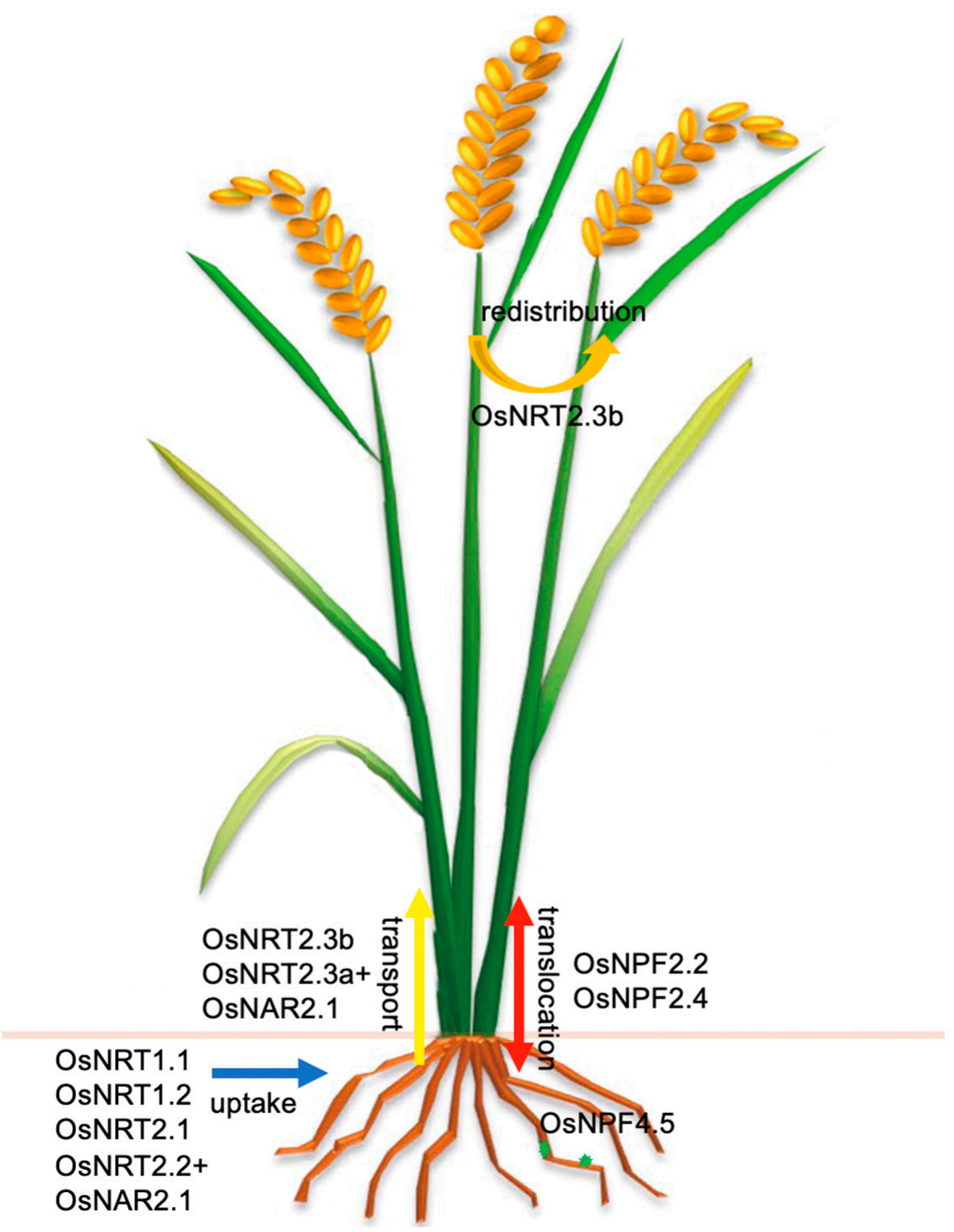

Figure 1. Summary of the contribution of $\mathrm{NO}_{3}{ }^{-}$transporters in rice. OsNRT1.1, OsNRT1.2, OsNRT2.1, and OsNRT2.2 (cooperating with OsNAR2.1) are responsible for $\mathrm{NO}_{3}{ }^{-}$uptake from the soil. OsNRT2.3a cooperating with OsNAR2.1 is responsible for root-to-shoot $\mathrm{NO}_{3}{ }^{-}$transport, and OsNRT2.3b is also responsible for transporting $\mathrm{NO}_{3}{ }^{-}$to the shoot and remobilizing $\mathrm{N}$ into the grain. OsNPF2.2 and OsNPF2.4 are involved in $\mathrm{NO}_{3}{ }^{-}$translocation. OsNPF4.5 is induced by mycorrhizal, involved in symbiotic $\mathrm{N}$ uptake. Blue line means $\mathrm{NO}_{3}{ }^{-}$uptake, yellow line means transport $\mathrm{NO}_{3}{ }^{-}$ from root to shoot, red line means $\mathrm{NO}_{3}{ }^{-}$translocation, orange line means $\mathrm{NO}_{3}{ }^{-}$redistribution. 
Table 1. Candidate $\mathrm{NO}_{3}{ }^{-}$transporter and regulation genes for crop application. NUE, nitrogen use efficiency.

\begin{tabular}{|c|c|c|c|c|c|}
\hline Gene & Accession NO. & Species & Characteristic & Nnitrogen Behavior & Reference \\
\hline OsTCP19 & Os06g12230 & Rice & $\begin{array}{l}\text { Responding to nitrate, negatively } \\
\text { regulate rice tillering }\end{array}$ & $\begin{array}{l}\text { High tilling response to } \\
\text { nitrogen }\end{array}$ & [2] \\
\hline OsNRT2.3b & AK072215 & Rice & $\begin{array}{l}\text { Enhancing } \mathrm{pH} \text { homeostasis, grain } \\
\text { yield and NUE }\end{array}$ & Uptake & [19] \\
\hline OsNRT2.3a & AK109776 & Rice & Root-to-shoot $\mathrm{NO}_{3}{ }^{-}$transport & Transport & {$[34]$} \\
\hline OsNAR2.1 & NC_029257.1 & Rice & $\begin{array}{c}\text { Interaction with } \\
\text { OsNRT2.1/2.2/2.3a }\end{array}$ & $\begin{array}{l}\text { Promote uptake and } \\
\text { transport after interaction }\end{array}$ & {$[29,33]$} \\
\hline OsNRT1.1B & Os10g40600 & Rice & Improving NUE in Indica rice & Uptake and transport & [6] \\
\hline OsNPF2.2 & Os12g44100 & Rice & $\begin{array}{l}\text { Unloading } \mathrm{NO}_{3}-\text { from the xylem } \\
\text { and effects on root-to-shoot } \\
\mathrm{NO}_{3}{ }^{-} \text {transport }\end{array}$ & Transport & {$[38]$} \\
\hline OsNPF2.4 & AK099321.1 & Rice & $\begin{array}{l}\text { Long-distance } \mathrm{NO}_{3}{ }^{-} \text {transport } \\
\text { and regulating } \mathrm{NO}_{3}{ }^{-} \text {and } \mathrm{K}^{+} \\
\text {shuttle }\end{array}$ & Uptake and transport & [39] \\
\hline OsNRT2.4 & Os01g36720 & Rice & $\begin{array}{l}\text { Dual-affinity nitrate transporter, } \\
\text { nitrate-regulated root growth }\end{array}$ & Uptake & {$[32]$} \\
\hline OsNRT1.1A & Os08g05910 & Rice & $\begin{array}{l}\text { Regulating N utilization and } \\
\text { flowering }\end{array}$ & Uptake & [20] \\
\hline OsNPF4.5 & Os01g54515 & Rice & $\begin{array}{c}\text { Low-affinity } \mathrm{NO}_{3}^{-} \text {transport } \\
\text { activity involved in symbiotic } \mathrm{N} \\
\text { uptake }\end{array}$ & Uptake & [35] \\
\hline OsNPF6.1 & Os01g01360 & Rice & $\begin{array}{l}\text { OsNPF6.1 } 1^{\text {HapB }} \text { enhances nitrate } \\
\text { uptake and confers high NUE by } \\
\text { increasing yield under low } \\
\text { nitrogen supply }\end{array}$ & Uptake & [15] \\
\hline OsNPF7.1 & Os07g41250 & Rice & regulates tillering and grain yield & Uptake & [40] \\
\hline OsNPF7.4 & Os04g50940 & Rice & regulates tillering and grain yield & Uptake and transport & {$[40]$} \\
\hline OsNPF7.2 & Os02g47090 & Rice & $\begin{array}{l}\text { positively regulates tiller number } \\
\text { and grain yield }\end{array}$ & Uptake and transport & [41] \\
\hline OsNPF7.7 & Os10g42870 & Rice & $\begin{array}{l}\text { regulate shoot branching and } \\
\text { nitrogen utilization efficiency }\end{array}$ & Uptake & [42] \\
\hline OsNPF7.3 & Os04g50950 & Rice & $\begin{array}{l}\text { contributes to nitrogen allocation } \\
\text { and grain yield }\end{array}$ & Translocation & [43] \\
\hline OsPTR9 & Os06g49250 & Rice & $\begin{array}{l}\text { nitrogen utilization efficiency and } \\
\text { grain yield }\end{array}$ & Uptake & {$[46]$} \\
\hline TaNAC2-5A & AY625683 & Wheat & $\begin{array}{l}\text { Positive control of } \mathrm{NO}_{3}^{-} \\
\text {transporter expression and } \\
\text { improving } \mathrm{NO}_{3}^{-} \text {accumulation } \\
\text { and plant growth }\end{array}$ & $\begin{array}{l}\text { Regualating TaNRT2.5 } \\
\text { Enhance nitrate uptake }\end{array}$ & [21] \\
\hline TaNRT2.1 & AF332214 & Wheat & $\begin{array}{c}\mathrm{NO}_{3}^{-} \text {uptake at post-flowering } \\
\text { stage }\end{array}$ & Uptake & [28] \\
\hline MtNRT2.1 & Medtr4g104730 & $\begin{array}{c}\text { M. } \\
\text { truncatula }\end{array}$ & $\begin{array}{l}\text { Nitrate transport with HATS } \\
\text { activity }\end{array}$ & Uptake & [47] \\
\hline MtNRT2.3 & Medtr4g057865 & $\begin{array}{c}\text { M. } \\
\text { truncatula }\end{array}$ & $\begin{array}{l}\text { Controlling post-inoculation } \\
\text { processes in nodule functioning }\end{array}$ & Transport & [47] \\
\hline MtNIP/LATD & GQ401665 & $\begin{array}{c}\text { M. } \\
\text { truncatula }\end{array}$ & $\begin{array}{l}\text { Controlling nodulation and root } \\
\text { architecture }\end{array}$ & Uptake & [48] \\
\hline LeNRT2.3 & AY038800 & Tomato & $\begin{array}{c}\mathrm{NO}_{3}^{-} \text {uptake and long-distance } \\
\text { transport }\end{array}$ & Uptake and transport & [27] \\
\hline
\end{tabular}


Table 1. Cont.

\begin{tabular}{|c|c|c|c|c|c|}
\hline Gene & Accession NO. & Species & Characteristic & Nnitrogen Behavior & Reference \\
\hline CmNRT2.1 & KT203959.1 & Chrysanthemun & Enhancing N uptake & Uptake & [49] \\
\hline AtNRT1.1 & AT1G12110 & Arabidopsis & $\begin{array}{l}\text { Directing root growth in sensing } \\
\text { external } \mathrm{NO}_{3}{ }^{-} \text {concentration }\end{array}$ & Uptake & {$[50]$} \\
\hline \multicolumn{2}{|c|}{ AtNPF7.3/AtNRT1.AT1G32450 } & Arabidopsis & $\begin{array}{l}\text { Low } \mathrm{NO}_{3}^{-} \text {dependent } \mathrm{K}^{+} \\
\text {translocation from root to shoot }\end{array}$ & Transport & {$[51,52]$} \\
\hline AtNRT1.11 & AT1G52190 & Arabidopsis & $\begin{array}{c}\text { Phloem-specific } \mathrm{NO}_{3}^{-} \\
\text {transporter redistributing } \\
\text { xylem-borne } \mathrm{NO}_{3}^{-} \text {to enhance } \\
\text { plant growth }\end{array}$ & Transport & {$[53]$} \\
\hline AtNRT1.12 & AT3G16180 & Arabidopsis & $\begin{array}{c}\text { Phloem-specific } \mathrm{NO}_{3}^{-} \\
\text {transporter redistributing } \\
\text { xylem-borne } \mathrm{NO}_{3}^{-} \text {to enhance } \\
\text { plant growth }\end{array}$ & Transport & [53] \\
\hline AtNPF2.3 & AT3G45680 & Arabidopsis & $\begin{array}{c}\mathrm{NO}_{3}{ }^{-} \text {excretion transporter and } \\
\text { contribution to } \mathrm{NO}_{3}^{-} \\
\text {translocation to the shoot }\end{array}$ & Transport & {$[54]$} \\
\hline AtNPF3.1 & AT1G68570 & Arabidopsis & $\begin{array}{l}\text { Encoding pathogen-inducible } \\
\mathrm{NO}_{3}{ }^{-} / \mathrm{NO}_{2}-\text { transporters }\end{array}$ & Uptake & {$[55]$} \\
\hline AtNPF5.5 & AT2G38100 & Arabidopsis & $\begin{array}{l}\text { Affecting } \mathrm{N} \text { accumulation in } \\
\text { Arabidopsis embryo }\end{array}$ & Uptake & [56] \\
\hline AtNRT2.5 & AT1G12940 & Arabidopsis & $\begin{array}{l}\text { Loading } \mathrm{NO}_{3}{ }^{-} \text {into phloem of } \\
\text { N-starved adult plants }\end{array}$ & Uptake andtransport & [57] \\
\hline AtNRT2.7 & AT5G14570 & Arabidopsis & $\begin{array}{c}\text { Seed-specific } \mathrm{NO}_{3}-\text { transporter } \\
\text { for accumulation/oxidation of } \\
\text { proanthocyanidins }\end{array}$ & Transport & [58] \\
\hline AtNLP7 & AT4G24020 & Arabidopsis & $\begin{array}{l}\text { Enhancing plant growth in } \\
\text { N-sufficient conditions }\end{array}$ & Sensing and assimilation & [59] \\
\hline AtHY5 & AT3G17609 & Arabidopsis & Binding NRT2.1 promoter & $\begin{array}{l}\text { Activating NRT2.1 } \\
\text { expression and nitrate } \\
\text { uptake }\end{array}$ & [60] \\
\hline
\end{tabular}

\section{Ammonium, Amino Acid and Nitrogen Assimilation Relative Genes Apply to NUE}

Rice grown in paddy fields is an ammonium $\left(\mathrm{NH}_{4}{ }^{+}\right)$-preferring crop. Ammonium is uptaken by ammonium transporters (AMTs) as well as aquaporins or cation channels [61-66]. Three members of the rice OsAMT1 gene family of ammonium transporters showed distinct expression patterns. OsAMT1;1 was constitutive and ammonium-induced expression in shoots and roots. OsAMT1;2 was specific expressed in root and ammoniuminducible. OsAMT1;3 was also root-specific expressed and repressed by nitrogen supply, and glutamine had the same effect on the transcriptional regulation of OsAMT1 genes as ammonium, indicating that glutamine rather than ammonium controls the expression of ammonium transporter genes in rice [62]. OsAMT1;1 mediates $\mathrm{NH}_{4}{ }^{+}$uptake at relatively lower affinity and mediates $\mathrm{NH}_{4}{ }^{+}$uptake in a proton independent manner [67]. OsAMT1;1 significantly contributes to the $\mathrm{NH}_{4}{ }^{+}$uptake under both low and high $\mathrm{NH}_{4}{ }^{+}$ conditions and increased seed yield under suboptimal and optimal $\mathrm{N}$ conditions $[68,69]$. Concomitant activation of OsAMT1;2 and OsGOGAT1 genes led to increased tolerance to nitrogen limitation and better ammonium uptake and $\mathrm{N}$ remobilization at the whole plant level [70]. Overexpression of OsAMT1;3 regulates rice growth and carbon-nitrogen metabolic status [71]. Many studies on the genetic manipulation of ammonium uptake of rice in improving NUE are limited. A recent study found that some transcription factors can regulate the expression of ammonium transporters to affect NUE [72]. OsNLP1 protein 
was localized in the nucleus and its transcription level was rapidly induced by nitrogen starvation. Overexpression of OsNLP1 increased plant growth, yield and NUE under different nitrogen conditions, while knockout of OsNLP1 decreased yield and NUE under nitrogen limitation. A further study suggests that OsNLP1 regulates ammonium and nitrate utilization by coordinating multiple nitrogen uptake and assimilation genes. Chromatin immunoprecipitation (CHIP) and yeast-one hybrid experiments showed that OsNLP1 could directly bind to the promoters of these genes and activate their expression. Overall, enhancing the absorption and remobilization of ammonium will provide a promising strategy to improve rice NUE in the future [73].

It has been proven that plants can obtain organic nitrogen, especially amino acids, through root localized transporters [73-75]. When amino acid in soil is relatively high, such as in organic agricultural soil or other planting systems relying on manure or compost for nitrogen nutrition, this absorption system is particularly important [76-78]. Some people think that compared with mineral nitrogen fertilizer, the application of high proportion of organic fertilizer can improve the nitrogen absorption, yield, and NUE of crops, and reduce the emission of organic nitrogen to the environment [79]. In rice, the overexpression of OsAAP1 resulted in increased $\mathrm{N}$ uptake and redistribution, as well as significantly increased tiller number and final yield [80]. OsAAP3 and OsAAP5 are mainly expressed in the vascular system of rice, and may participate in the transport of amino acids between xylem and phloem [81,82]. RNAi lines of OsAAP3 and OsAAP5 also showed significant improvements in tiller number and yield under sufficient nitrogen conditions. Genetic association analyses with 68 representatives Japonica or Indica germplasms identified that OsLHT1 has a natural variation in aspartate absorption between Japonica and Jndica, and OsLHT1 functions in a broad spectrum of amino acids, and effectively transported aspartate, asparagine, and glutamate in yeast cells. OsLHT1 is responsible for both the root uptake and root to shoot allocation of a broad spectrum of amino acids in rice [83].

After being absorbed into the plant, the assimilation process is the same except that nitrate needs to be reduced to $\mathrm{NH}_{4}{ }^{+}$(NH3). Nitrate is reduced to nitrite in the cytoplasm and transported to the plastid for further reduction to ammonium [84-87]. The twostep reduction was achieved by nitrate reductase (NR) and nitrite reductase (NIR). NR is the main regulatory step in the process of nitrogen assimilation, and its activity is highly regulated by nitrate, light or water availability [88-91]. The overexpression of NR or NIR often leads to increased N uptake. Recent studies on rice have shown that the overexpression of Indica OsNR2 in Japonica can increase tiller number, grain yield, and NUE under high nitrogen supply [8]. This effect was better when Indica OsNR2 and OsNRT1.1b were concurrently expressed, indicating that OsNR2 could regulate OsNRT1.1b and thus nitrate uptake [8]. The overexpression of OsNADH-GOGAT in rice by its native promoter also resulted in increased grain weight at low $\mathrm{N}$ fertilization [92]. Interestingly, the combined overexpression of OsAMT1;2 and OsNADH-GOGAT1 in rice can increase NUE in rice under both sufficient and low nitrogen conditions [54]. The results suggest that concurrently increasing $\mathrm{N}$ uptake and $\mathrm{N}$ assimilation could improve NUE. Some autophagy-related gene could enhance $\mathrm{N}$ remobilization and yield and NUE. For example, the overexpression of OsATG8a in rice could increase shoot biomass, yield, and NUE when transgenic plants were exposed to high $\mathrm{N}$ conditions [93], while overexpression of OsATG $8 b$ led to increased biomass, yield, and NUE at moderate and low N [94]. Similarly, the constitutive expression of OsATG $8 b$ in rice led to more biomass and higher grain yield under sufficient $\mathrm{N}$ conditions [95], and the overexpression of OsATG8c led to improvements in shoot biomass, grain yield, and NUE under moderate and low $\mathrm{N}$ fertilization [96].

Too much uptake with a slower assimilation of ammonium may lead to ammonium toxicity and damage to plant growth. Glutamine synthetase is the key enzyme of ammonia assimilation in plants. Ammonium was the main nitrogen source in rice plants, which was assimilated into glutamine and glutamic acid by glutamine synthetase (GS). Glutamine and Glutamic Acid were the fundamental nitrogen sources of other amino acids biosynthesis [97-99]. GS has two isomers, cytoplasmic GS1 and plastidic GS2, which 
have different functions in nitrogen assimilation $[100,101]$. GS1 isoforms are mainly involved in nitrogen reassimilation and reuse. GS2 participates in primary nitrogen assimilation [102,103]. OsGS1;1 is involved in ammonium assimilation in rice shoot and root [104]. The overexpression of glutamine synthetase genes GS1 and GS2 in transgenic rice plants increases nitrogen-deficiency tolerance [105] and the simultaneous overexpression of OsGS1 and OsGS2 genes enhanced the tolerance to osmotic and salinity stress at the seedling stage. There are many examples of using GS gene to improve NUE in multiple species, including Tobacco [106-109], Arabidopsis [110], Sorghum [111], Maize [112], common wheat [113,114], Barley [115], and Rice [98,116,117]. However, not all GS genes can play a positive role after overexpression, and in some cases, they may have negative effects on plants [106,116-120]. In general, it is possible to use nitrogen assimilation genes to improve the NUE of rice, but this requires the coordination of all aspects of rice development and nutrient condition.

\section{Plant Hormones Act on NUE}

Strigolactones (SLs) have been reported to function in the nutrient-dependent regulation of root and shoot architecture. The biosynthesis mutant dwarf 10 (d10) had a higher $\mathrm{N}$ concentration in older leaves but a lower $\mathrm{N}$ concentration in younger leaves, while the SL-signaling mutant dwarf 3 (d3) mutant showed a considerably lower N concentration, especially in its younger leaves under normal $\mathrm{N}$ levels. Both $d 3$ and $d 10$ mutants possess higher $\mathrm{N}$ in their leaves under $\mathrm{N}$-deficient conditions. The analysis of uptake and distribution of ${ }^{15} \mathrm{~N}$ showed that the significant difference of nitrogen concentration between $d 3, d 10$, and WT plants occurred only in leaves, not in roots. The SLS synthesized by exogenous GR24 changed the leaf $\mathrm{N}$ distribution of $d 10$ mutant but did not change the leaf N distribution of $d 3$ mutant and WT, indicating that the effects of SLS on rice growth and development may be related to the transport of nitrogen to different shoot tissues [121]. AUXIN is a looping star in plant development [122]. A rice nitrogen relative QTL named DULL NITROGEN RESPONSE1 ( $q$ DNR1) involved in auxin homeostasis, reflects the differences in nitrate $\left(\mathrm{NO}_{3}{ }^{-}\right)$uptake, $\mathrm{N}$ assimilation, and yield enhancement between Indica and Japonica rice varieties. Rice plants carrying the DNR1 Indica allele exhibit reduced N-responsive transcription and protein abundance of DNR1 and promotes auxin biosynthesis, inducing AUXIN RESPONSE FACTOR-mediated activation of $\mathrm{NO}_{3}{ }^{-}$ transporter and N-metabolism genes, resulting in improved NUE and grain yield. Lossof-function mutation at the DNR1 locus increased N uptake and assimilation, resulting in improved rice yield under moderate levels of $\mathrm{N}$ fertilizer input [123]. An auxin efflux carrier OsPIN9 was induced by ammonium, compared to single nitrate, and involved in ammonium induced rice tillering in rice. The overexpression of OsPIN9 increased yield under low nitrogen condition [124]. Therefore, appropriate modulation of auxin response is also a promising strategy for achieving NUE in rice. Gibberellin acid (GA) plays a crucial role in agricultural green revolution. The rice $s d 1$ allele is shorter than normal plants given the reduction of gibberellin, and this increases accumulation of the rice DELLA protein SLR1 (SLENDER RICE1) [125-127]. The plants are shorter and therefore more resistant to lodging [128]. Transcription factor NGR5 (N-mediated tiller growth response 5) is the target of gibberellin receptor gibberellin insensitive dwarf 1 (GID1), promoting proteasome destruction. NGR5 promotes the N-dependent recruitment of polycomb inhibitor complex 2 through H3K27me3 modification to inhibit branching inhibitors. DELLA protein competitively inhibited GID1-NGR5 interaction, and explained the reason for the tillering increase of green revolution varieties. The increase of NGR5 activity resulted in the decoupling of tillering and nitrogen regulation, thus increasing rice yield at low nitrogen level. Therefore, optimal use of GA could improve the NUE and improve the sustainability of agriculture in the future [129]. Abscisic acid (ABA) is a dominant regulator in plants facing abiotic stress. Osmotic stress/ABA-activated protein kinase 2 (SAPK2) is a member of SnRK2s in rice. The ossapk2 mutants were shorter and produced fewer grains per panicle, smaller grains, and lower grain yield under drought stress. Moreover, SAPK2 consider- 
ably influences the nitrogen contents of rice grains and $\mathrm{NO}_{3}{ }^{-}$influx rate, while nitrate concentration analysis indicated that SAPK2 promotes nitrate uptake and assimilation by regulating nitrate-related transporters. These results suggest that $\mathrm{ABA}$ related gene could also enhance grain production by regulating NUE under drought stress. Jasmonates (JAs) represent a kind of lipid derived plant hormone, which plays an important role in plant development and defense response to insects. The exogenous addition of methyl jasmonate (MeJA) to rice seedlings significantly reduced root $\mathrm{N}$ uptake and ${ }^{15} \mathrm{~N}$ transport from root to leaf, possibly due to the downregulation of glutamine synthetase and nitrite ferredoxin. MeJA treatment of shoot resulted in the reactivation of endogenous nitrogen from leaf to root. MeJA treatment of root also increased the accumulation of ${ }^{14} \mathrm{~N}$ in roots, but did not affect the accumulation of ${ }^{14} \mathrm{~N}$ in leaves. Subsequent analysis of proteomics and RT-qPCR showed that the up regulation of $G D H 2$, a plastid disintegration dehydrogenase mediated by JA, contributed to the release of nitrogen in leaves and supported the production of defense proteins/compounds under nitrogen limitation [130]. JA signaling mediates largescale systemic changes in nitrogen uptake and distribution in rice. Cytokinins affect many aspects of plant growth and development. The overexpression of cytokinin-activation enzyme-like gene OsLOGL5 significantly reduced primary root growth, tiller number, and yield. On the contrary, a mutation in the C-terminal of OsLOGL5 led to normal plant morphology, but rice yield increased under the conditions of sufficient water, drought, normal nitrogen, and low nitrogen in multiple geographical locations. It was found that the C-terminal of OsLOGL5 protein played an important role in regulating rice yield and improving NUE under different abiotic stresses [131]. In summary, these results suggest that the reasonable use of hormones can also significantly improve the NUE of rice under various growth conditions.

\section{Future Perspectives}

Increasing crop NUE can be achieved by increasing crop yield under the same nitrogen supply or using less nitrogen input for sustainable productivity. A lot of work is now devoted to the identification of candidate genes in improving NUE and their regulatory networks. The basic mechanisms of local and systematic $\mathrm{N}$ sensing, uptake, transport, assimilation, and remobilization have been well studied in Arabidopsis, which should be pursued in rice [132]. With the development of bioinformatics, using a high-quality genome sequence, assembly, annotation, and the genome-wide association study (GWAS) of natural genetic variation will further accelerate the discovery of key genes and pathways related to NUE traits in rice. Recently, a new genomic analysis of 33 rice genetic diversity revealed multiple structural variations and gene copy number variations [133]. In order to make use of the variation and phenotype information, researchers should speed up the molecular breeding of these important traits.

Using gene editing by CRISPR-Cas9 technology to change the expression pattern of some genes is a choice for precision agriculture [134]. Nitrate transporters can be effectively used to improve crop yield and through genome editing. Changing the expression of some nitrate transporters or their regulators can improve the NUE in crops $[6,19,21-25,135,136]$. However, it is not the best way to improve NUE by simply aggregating single positive alleles in rice. The overexpression of multiple genes at the same time can improve the nitrogen use efficiency of more rice. For example, compared with WT, the influx rate of ${ }^{15} \mathrm{NO}_{3}{ }^{-}$, agronomic nitrogen use efficiency, and nitrogen recovery efficiency of OsNRT2.1 or OsNAR2.1 overexpression lines increased by $10 \%, 20 \%$, and $30 \%$, respectively, while the co-overexpression of OsNRT2.1 and OsNAR2.1 lines increased by $40 \%, 50 \%$, and $60 \%$, respectively (Figure 2). The elite haplotype OsNPF6.1 ${ }^{\text {HapB }}$ improves NUE under low nitrogen conditions, which was activated by OsNAC42 [37]. Indica OsNR2 promotes $\mathrm{NO}_{3}{ }^{-}$uptake by feedback interaction OsNRT1.1B (8), which increased effective tiller number, grain yield, and NUE. Therefore, the co-expression of OsNAC42-OsNPF6.1 $1^{\text {HapB }}$ cascade, Indica OsNR2-OsNRT1.1B could improve NUE in rice. In the future molecular breeding, there must be a balance between these genes and pathways, which necessitates 
better coordination. A potential direction is to find out all possible expression patterns of some useful genes during rice development under various conditions. Using genomic and phenotypic data to explore the best coordinated expression pattern of the regulatory network will deepen our understanding of the determinants for improving NUE. The optimized NUE should meet the best nitrogen demand of rice and be environmentally friendly.
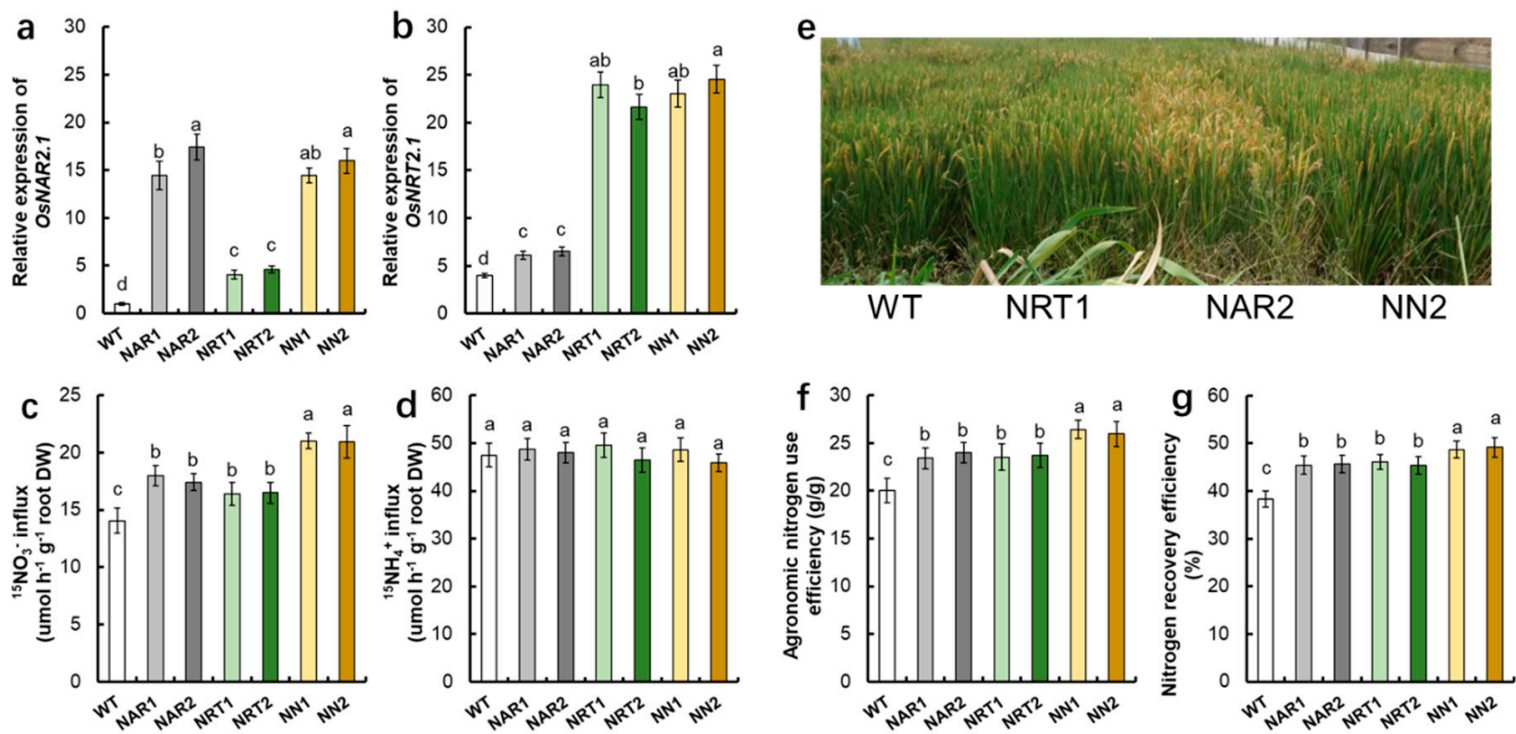

Figure 2. Co-overexpression of OsNRT2.1 and OsNAR2.1 increased nitrogen use efficiency in transgenic rice plants. qRT-PCR analysis showed the expression of (a) OsNAR2.1 and (b) OsNRT2.1 of WT, p35S:OsNAR2.1 transgenic lines (NAR1, NAR2), p35S:OsNRT2.1 transgenic lines (NRT1, NRT2), and p35S:OsNAR2.1-p35S:OsNRT2.1 transgenic lines (NN1, NN2). RNA was extracted from root. Error bars: SE $(n=3)$. (c,d $){ }^{15} \mathrm{~N}$ influx rates of transgenic lines. WT and transgenic seedlings were grown in $1 \mathrm{mM} \mathrm{NH}_{4}{ }^{+}$for 3 weeks and nitrogen starved for 1 week. ${ }^{15} \mathrm{~N}$ influx rates were then measured at (c) 0.5 $\mathrm{mM}^{15} \mathrm{NO}_{3}{ }^{-}$, (d) $0.5 \mathrm{mM}^{15} \mathrm{NH}_{4}{ }^{+}$during 5 min. DW, dry weight. (e) Photograph of WT and transgenic lines in the field experiment. Comparison of (f) agronomic nitrogen use efficiency and (g) nitrogen recovery efficiency between the NP and transgenic lines. Error bars: SE $(n=4)$. The different letters indicate a significant difference between the transgenic line and the WT $(p<0.05$, one-way ANOVA).

Author Contributions: M.H. and J.C. wrote the first draft of the manuscript and organized the tables and figures; M.Y., Z.L. and Z.A. reviewed the manuscript. All authors have read and agreed to the published version of the manuscript.

Funding: This research was financially supported by the National Natural Science Foundation of China (31902103, 32061143039).

Institutional Review Board Statement: Not applicable.

Informed Consent Statement: Not applicable.

Data Availability Statement: All data generated or analyzed during this study are included in this published article.

Conflicts of Interest: The authors declare no conflict of interest.

\section{References}

1. Guo, J.H.; Liu, X.J.; Zhang, Y.; Shen, J.L.; Han, W.X.; Zhang, W.F.; Christie, P.; Goulding, K.W.T.; Vitousek, P.M.; Zhang, F.S. Significant acidification in major Chinese croplands. Science 2010, 327, 1008-1010. [CrossRef]

2. Liu, Y.; Wang, H.; Jiang, Z.; Wang, W.; Xu, R.; Wang, Q.; Zhang, Z.; Li, A.; Liang, Y.; Ou, S.; et al. Genomic basis of geographical adaptation to soil nitrogen in rice. Nature 2021, 590, 600-605. [CrossRef] [PubMed]

3. Zhou, Y.; Tao, Y.; Tang, D.; Wang, J.; Zhong, J.; Wang, Y.; Yuan, Q.; Yu, X.; Zhang, Y.; Wang, Y.; et al. Identification of QTL Associated with Nitrogen Uptake and Nitrogen Use Efficiency Using High Throughput Genotyped CSSLs in Rice (Oryza sativa L.). Front. Plant Sci. 2017, 8, 1166. [CrossRef] 
4. Tang, J.; Sun, Z.; Chen, Q.; Damaris, R.N.; Lu, B.; Hu, Z. Nitrogen Fertilizer Induced Alterations in The Root Proteome of Two Rice Cultivars. Int. J. Mol. Sci. 2019, 20, 3674. [CrossRef]

5. Sasaki, T.; Burr, B. International rice genome sequencing project: The effort to completely sequence the rice genome. Curr. Opin. Plant Biol. 2000, 3, 138-142. [CrossRef]

6. Hu, B.; Wang, W.; Doug, S.J.B.; Tang, J.Y.; Li, H.; Che, R.H.; Zhang, Z.H.; Chai, X.Y.; Wang, H.R.; Wang, Y.Q.; et al. Variation in NRT1.1B contributes to nitrate-use divergence between rice subspecies. Nat. Genet. 2015, 47, 834-838. [CrossRef]

7. Zhu, J.; Liang, J.; Xu, Z.; Fan, X.; Zhou, Q.; Shen, Q.; Xu, G. Root aeration improves growth and $\mathrm{N}$ accumulation in rice seedlings under low nitrogen. AoB Plants 2015, 7, plv131. [CrossRef]

8. Gao, Z.; Wang, Y.; Chen, G.; Zhang, A.; Yang, S.; Shang, L.; Wang, D.; Ruan, B.; Liu, C.; Jiang, H.; et al. The indica nitrate reductase gene OsNR2 allele enhances rice yield potential and nitrogen use efficiency. Nat. Commun. 2019, 10, 5207. [CrossRef]

9. Zhang, Z.H.; Chu, C.C. Nitrogen-Use Divergence Between Indica and Japonica Rice: Variation at Nitrate Assimilation. Mol. Plant 2020, 13, 6-7. [CrossRef]

10. Shan, Y.H.; Wang, Y.L.; Yoshinori, Y. Genotypic difference of nitrogen use efficiency in various types of indica rice. Jiangsu Agric. Res. 2001, 1, 12-15.

11. Shan, Y.H.; Wang, Y.L.; Pan, X.B. Mapping of QTLs for nitrogen use efficiency and related traits in rice (Oryza sativa L). Acta Agron. Sin. 2005, 4, 721-727.

12. Li, Y.; Li, M.; Cao, G.; Han, L. Effects of genetic background on expression of QTL for nitrogen efficiency in irrigated rice and upland rice. Sci. Agric. Sin. 2010, 43, 4331-4340.

13. Lian, X.; Xing, Y.; Yan, H.; Xu, C.; Li, X.; Zhang, Q. QTLs for low nitrogen tolerance at seedling stage identified using a recombinant inbred line population derived from an elite rice hybrid. Appl. Genet. 2005, 112, 85-96. [CrossRef]

14. Wei, D.; Cui, K.; Ye, G.; Pan, J.; Xiang, J.; Huang, J.; Nie, L. QTL mapping for nitrogen-use efficiency and nitrogen-deficiency tolerance traits in rice. Plant Soil 2012, 359, 281-295. [CrossRef]

15. Wang, Q.; Nian, J.; Xie, X.; Yu, H.; Zhang, J.; Bai, J.; Dong, G.; Hu, J.; Bai, B.; Chen, L.; et al. Genetic variations in ARE1 mediate grain yield by modulating nitrogen utilization in rice. Nat. Commun. 2018, 9, 735. [CrossRef]

16. Li, Y.; Fan, X.; Shen, Q. The relationship between rhizosphere nitrification and nitrogen-use efficiency in rice plants. Plant Cell Env. 2008, 31, 73-85. [CrossRef]

17. Kirk, G. Plant-mediated processess to acquire nutrients: Nitrogen uptake by rice plants. Plant Soil 2001, 232, 129-134. [CrossRef]

18. Duan, Y.; Zhang, Y.; Ye, L.; Fan, X.; Xu, G.; Shen, Q. Responses of rice cultivars with different nitrogen use efficiency to partial nitrate nutrition. Ann. Bot. 2007, 99, 1153-1160. [CrossRef]

19. Fan, X.; Tang, Z.; Tan, Y.; Zhang, Y.; Luo, B.; Yang, M.; Lian, X.; Shen, Q.; Miller, A.J.; Xu, G. Overexpression of a pH-sensitive nitrate transporter in rice increases crop yields. Proc. Natl. Acad. Sci. USA 2016, 113, 7118-7123. [CrossRef]

20. Wang, W.; Hu, B.; Yuan, D.; Liu, Y.; Che, R.; Hu, Y.; Ou, S.; Liu, Y.; Zhang, Z.; Wang, H.; et al. Expression of the nitrate transporter gene OsNRT1.1A/OsNPF6.3 confers high yield and early maturation in rice. Plant Cell 2018, 30, 638-651. [CrossRef]

21. He, X.; Qu, B.; Li, W.; Zhao, X.; Teng, W.; Ma, W.; Ren, Y.; Li, B.; Li, Z.; Tong, Y. The nitrate-inducible NAC transcription factor TaNAC2-5A controls nitrate response and increases wheat yield. Plant Physiol. 2015, 169, 1991-2005. [CrossRef]

22. Chen, J.; Fan, X.; Qian, K.; Zhang, Y.; Song, M.; Liu, Y.; Xu, G.; Fan, X. pOsNAR2.1:OsNAR2.1 expression enhances nitrogen uptake efficiency and grain yield in transgenic rice plants. Plant Biotechnol. J. 2017, 15, 1273-1283. [CrossRef]

23. Chen, J.; Liu, X.; Liu, S.; Fan, X.; Zhao, L.; Song, M.; Fan, X.; Xu, G. Co-overexpression of OsNRT2.3a and OsNAR2.1 increased agronomic nitrogen use efficiency in transgenic rice plants. Front. Plant Sci. 2020, 11, 1245. [CrossRef]

24. Chen, J.; Qi, T.; Hu, Z.; Fan, X.; Zhu, L.; Iqbal, M.F.; Yin, X.; Xu, G.; Fan, X. OsNAR2.1 Positively Regulates Drought Tolerance and Grain Yield Under Drought Stress Conditions in Rice. Front. Plant Sci. 2019, 10, 197. [CrossRef] [PubMed]

25. Chen, J.; Zhang, Y.; Tan, Y.; Zhang, M.; Zhu, L.; Xu, G.; Fan, X. Agronomic nitrogen-use efficiency of rice can be increased by driving OsNRT2.1 expression with the OsNAR2.1 promoter. Plant Biotechnol. J. 2016, 14, 1705-1715. [CrossRef] [PubMed]

26. Feng, H.; Li, B.; Zhi, Y.; Chen, J.; Li, R.; Xia, X.; Xu, G.; Fan, X. Overexpression of the nitrate transporter, OsNRT2.3b, improves rice phosphorus uptake and translocation. Plant Cell Rep. 2017, 36, 1287-1296. [CrossRef] [PubMed]

27. Fu, Y.; Yi, H.; Bao, J.; Gong, J. LeNRT2.3 functions in nitrate acquisition and long-distance transport in tomato. FEBS Lett. 2015, 589, 1072-1079. [CrossRef] [PubMed]

28. Taulemesse, F.; Le, G.J.; Gouache, D.; Gibon, Y.; Allard, V. Postflowering nitrate uptake in wheat is controlled by N status at flowering, with a putative major role of root nitrate transporter NRT2.1. PLoS ONE 2015, 10, e0120291. [CrossRef]

29. Yan, M.; Fan, X.; Feng, H.; Miller, A.J.; Shen, Q.; Xu, G. Rice OsNAR2.1 interacts with OsNRT2.1, OsNRT2.2 and OsNRT2.3a nitrate transporters to provide uptake over high and low concentration ranges. Plant Cell Environ. 2011, 34, 1360-1372. [CrossRef]

30. Feng, H.; Yan, M.; Fan, X.; Li, B.; Shen, Q.; Miller, A.J.; Xu, G. Spatial expression and regulation of rice high-affinity nitrate transporters by nitrogen and carbon status. J. Exp. Bot. 2011, 62, 2319-2332. [CrossRef]

31. Song, M.; Fan, X.; Chen, J.; Qu, H.; Luo, L.; Xu, G. OsNAR2.1 Interaction with OsNIT1 and OsNIT2 Functions in Root-growth Responses to Nitrate and Ammonium. Plant Physiol. 2020, 183, 289-303. [CrossRef]

32. Wei, J.; Zheng, Y.; Feng, H.; Qu, H.; Fan, X.; Yamaji, N.; Ma, J.F.; Xu, G. OsNRT2.4 encodes a dual-affinity nitrate transporter and functions in nitrate-regulated root growth and nitrate distribution in rice. J. Exp. Bot. 2018, 69, 1095-1107. [CrossRef] 
33. Liu, X.; Huang, D.; Tao, J.; Miller, A.J.; Fan, X.; Xu, G. Identification and functional assay of the interaction motifs in the partner protein OsNAR2.1 of the two-component system for high-affinity nitrate transport. New Phytol. 2014, 204, 74-80. [CrossRef] [PubMed]

34. Tang, Z.; Fan, X.; Li, Q.; Feng, H.; Miller, A.J.; Shen, Q.; Xu, G. Knockdown of a Rice Stelar Nitrate Transporter Alters Long-Distance Translocation but Not Root Influx. Plant Physiol. 2012, 160, 2052-2063. [CrossRef] [PubMed]

35. Wang, S.; Chen, A.; Xie, K.; Yang, X.; Luo, Z.; Chen, J.; Zeng, D.; Ren, Y.; Yang, C.; Wang, L.; et al. Functional analysis of the OsNPF4.5 nitrate transporter reveals a conserved mycorrhizal pathway of nitrogen acquisition in plants. Proc. Natl. Acad. Sci. USA 2020, 117, 16649-16659. [CrossRef]

36. Hu, B.; Jiang, Z.; Wang, W.; Qiu, Y.; Zhang, Z.; Liu, Y.; Li, A.; Gao, X.; Liu, L.; Qian, Y.; et al. Nitrate-NRT1.1B-SPX4 cascade integrates nitrogen and phosphorus signalling networks in plants. Nat. Plants. 2019, 5, 401-413. [CrossRef]

37. Tang, W.; Ye, J.; Yao, X.; Zhao, P.; Xuan, W.; Tian, Y.; Zhang, Y.; Xu, S.; An, H.; Chen, G.; et al. Genome-wide associated study identifies NAC42-activated nitrate transporter conferring high nitrogen use efficiency in rice. Nat. Commun. 2019, 10, 5279. [CrossRef] [PubMed]

38. Li, Y.; Ouyang, J.; Wang, Y.Y.; Hu, R.; Xia, K.; Duan, J.; Wang, Y.; Tsay, Y.F.; Zhang, M. Disruption of the rice nitrate transporter OsNPF2.2 hinders root-to-shoot nitrate transport and vascular development. Sci. Rep. 2015, 5, 9635. [CrossRef] [PubMed]

39. Xia, X.; Fan, X.; Wei, J.; Feng, H.; Qu, H.; Xie, D.; Miller, A.J.; Xu, G. Rice nitrate transporter OsNPF2.4 functions in low-affinity acquisition and longdistance transport. J. Exp. Bot. 2015, 66, 317-331. [CrossRef] [PubMed]

40. Huang, W.T.; Nie, H.P.; Feng, F.; Wang, J.; Lu, K.; Fang, Z.M. Altered expression of OsNPF7.1 and OsNPF7.4 differentially regulates tillering and grain yield in rice. Plant Sci. 2019, 283, 23-31. [CrossRef] [PubMed]

41. Wang, J.; Lu, K.; Nie, H.P.; Zeng, Q.S.; Wu, B.W.; Qian, J.J.; Fang, Z.M. Rice nitrate transporter OsNPF7.2 positively regulates tiller number and grain yield. Rice 2018, 11, 12. [CrossRef]

42. Huang, W.T.; Bai, G.X.; Wang, J.; Zhu, W.; Zeng, Q.S.; Lu, K.; Sun, S.Y.; Fang, Z.M. Two splicing variants of OsNPF7.7 regulate shoot branching and nitrogen utilization efficiency in rice. Front. Plant Sci. 2018, 9, 300. [CrossRef]

43. Fang, Z.M.; Bai, G.X.; Huang, W.T.; Wang, Z.X.; Wang, X.L.; Zhang, M.Y. The rice peptide transporter OsNPF7.3 is induced by organic nitrogen, and contributes to nitrogen allocation and grain yield. Front. Plant Sci. 2017, 8, 1338. [CrossRef]

44. Wu, J.; Zhang, Z.; Xia, J.; Alfatih, A.; Song, Y.; Huang, Y.; Wan, G.; Sun, L.; Tang, H.; Liu, Y.; et al. Rice NIN-LIKE PROTEIN 4 plays a pivotal role in nitrogen use efficiency. Plant Biotechnol. J. 2021, 19, 448-461. [CrossRef]

45. Yu, J.; Xuan, W.; Tian, Y.; Fan, L.; Sun, J.; Tang, W.; Chen, G.; Wang, B.; Liu, Y.; Wu, W.; et al. Enhanced OsNLP4-OsNiR cascade confers nitrogen use efficiency by promoting tiller number in rice. Plant Biotechnol. J. 2021, 19, 167-176. [CrossRef]

46. Fang, Z.M.; Xia, K.F.; Yang, X.; Suter, M.; Meier, S.; Rentsch, D.; Xu, X.L.; Zhang, M.Y. Altered expression of the PTR/NRT1 homologue OsPTR9 affects nitrogen utilization efficiency, growth and grain yield in rice. Plant Biotechnol. J. 2013, 11, 446-458. [CrossRef]

47. Pellizzaro, A.; Clochard, T.; Planchet, E.; Limami, A.M.; Morere-Le Paven, M.C. Identification and molecular characterization of Medicago truncatula NRT2 and NAR2 families. Physiol. Plant. 2015, 154, 256-269. [CrossRef]

48. Bagchi, R.; Salehin, M.; Adeyemo, O.S.; Salazar, C.; Shulaev, V.; Sherrier, D.J.; Dickstein, R. Functional assessment of the Medicago truncatula NIP/LATD protein demonstrates that it is a high-affinity nitrate transporter. Plant Physiol. 2012, 160, 906-916. [CrossRef] [PubMed]

49. Gu, C.; Song, A.; Zhang, X.; Wang, H.; Li, T.; Chen, Y.; Jiang, J.; Chen, F.; Chen, S. Cloning of chrysanthemum high affinity nitrate transporter family (CmNRT2) and characterization of CmNRT2.1. Sci. Rep. 2016, 6, 23462. [CrossRef] [PubMed]

50. Mounier, E.; Pervent, M.; Ljung, K.; Gojon, A.; Nacry, P. Auxin mediated nitrate signalling by NRT1.1 participates in the adaptive response of Arabidopsis root architecture to the spatial heterogeneity of nitrate availability. Plant Cell Environ. 2014, 37, 162-174. [CrossRef] [PubMed]

51. Meng, S.; Peng, J.S.; He, Y.N.; Zhang, G.B.; Yi, H.Y.; Fu, Y.L.; Gong, J.M. Arabidopsis NRT1.5 mediates the suppression of nitrate starvation induced leaf senescence by modulating foliar potassium level. Mol. Plant. 2016, 9, 461-470. [CrossRef]

52. Drechsler, N.; Zheng, Y.; Bohner, A.; Nobmann, B.; von Wiren, N.; Kunze, R.; Rausch, C. Nitrate-dependent control of shoot K homeostasis by the nitrate transporter1/peptide transporter family member NPF7.3/ NRT1.5 and the stelar $\mathrm{K}^{+}$outward rectifier SKOR in Arabidopsis. Plant Physiol. 2015, 169, 2832-2847. [PubMed]

53. Hsu, P.K.; Tsay, Y.F. Two phloem nitrate transporters, NRT1.11 and NRT1.12, are important for redistributing xylem-borne nitrate to enhance plant growth. Plant Physiol. 2013, 163, 844-856. [CrossRef]

54. Taochy, C.; Gaillard, I.; Ipotesi, E.; Oomen, R.; Leonhardt, N.; Zimmermann, S.; Boyer, J.C. The Arabidopsis root stele transporter NPF2.3 contributes to nitrate translocation to shoots under salt stress. Plant J. 2015, 83, 466-479. [CrossRef]

55. Pike, S.; Gao, F.; Kim, M.J.; Kim, S.H.; Schachtman, D.P.; Gassmann, W. Members of the NPF3 transporter subfamily encode pathogen inducible nitrate/nitrite transporters in grapevine and Arabidopsis. Plant Cell Physiol. 2014, 55, 162-170. [CrossRef] [PubMed]

56. Leran, S.; Garg, B.; Boursiac, Y.; Corratg-Faillie, C.; Brachet, C.; Tillard, P.; Gojon, A.; Lacombe, B. AtNPF5.5, a nitrate transporter affecting nitrogen accumulation in Arabidopsis embryo. Sci. Rep. 2015, 5, 7962. [CrossRef]

57. Lezhneva, L.; Kiba, T.; Feria-Bourrellier, A.B.; Lafouge, F.; Boutet-Mercey, S.; Zoufan, P.; Sakakibara, H.; Daniel-Vedele, F.; Krapp, A. The Arabidopsis nitrate transporter NRT2.5 plays a role in nitrate acquisition and remobilization in nitrogen-starved plants. Plant J. 2014, 80, 230-241. [CrossRef] 
58. David, L.C.; Dechorgnat, J.; Berquin, P.; Routaboul, J.M.; Debeaujon, I.; Daniel-Vedele, F.; Ferrario-Mery, S. Proanthocyanidin oxidation of Arabidopsis seeds is altered in mutant of the high-affinity nitrate transporter NRT2.7. J. Exp. Bot. 2014, 65, 885-893. [CrossRef]

59. Yu, L.H.; Wu, J.; Tang, H.; Yuan, Y.; Wang, S.M.; Wang, Y.P.; Zhu, Q.S.; Li, S.G.; Xiang, C.B. Overexpression of Arabidopsis NLP7 improves plant growth under both nitrogen-limiting and -sufficient conditions by enhancing nitrogen and carbon assimilation. Sci. Rep. 2016, 6, 27795. [CrossRef] [PubMed]

60. Chen, X.; Yao, Q.; Gao, X.; Jiang, C.; Harberd, N.P.; Fu, X. Shoot-to root mobile transcription factor HY5 coordinates plant carbon and nitrogen acquisition. Curr. Biol. 2016, 26, 640-646. [CrossRef] [PubMed]

61. Glass, A.D.; Britto, D.T.; Kaiser, B.N.; Kinghorn, J.R.; Kronzucker, H.J.; Kumar, A.; Vidmar, J.J.; Siddiqi, M.Y.; Rawat, S.; Okamoto, M.; et al. The regulation of nitrate and ammonium transport systems in plants. J. Exp. Bot. 2002, 53, 855-864. [CrossRef] [PubMed]

62. Sonoda, Y.; Ikeda, A.; Saiki, S.; Wirén, N.V.; Yamaya, T.; Yamaguchi, J. Distinct expression and function of three ammonium transporter genes (OsAMT1;1-1;3) in rice. Plant Cell Physiol. 2003, 44, 726-734. [CrossRef] [PubMed]

63. Jahn, T.P.; Møller, A.L.; Zeuthen, T.; Holm, L.M.; Klaerke, D.A.; Mohsin, B.; Kühlbrandt, W.; Schjoerring, J.K. Aquaporin homologues in plants and mammals transport ammonia. FEBS Lett. 2004, 574, 31-36. [CrossRef] [PubMed]

64. Loqué, D.; von Wirén, N. Regulatory levels for the transport of ammonium in plant roots. J. Exp. Bot. 2004, 55, 1293-1305. [CrossRef]

65. Guo, S.; Kaldenhoff, R.; Uehlein, N.; Sattelmacher, B.; Brueck, H. Relationship between water and nitrogen uptake in nitrate-and ammoniumsupplied Phaseolus vulgaris L. plants. J. Plant Nutr. Soil Sci. 2017, 170, 73-80. [CrossRef]

66. Bárzana, G.; Aroca, R.; Bienert, G.P.; Chaumont, F.; Ruiz-Lozano, J.M. New insights into the regulation of aquaporins by the arbuscular mycorrhizal symbiosis in maize plants under drought stress and possible implications for plant performance. Mol. Plant Microbe Interact. 2014, 27, 349-363. [CrossRef] [PubMed]

67. Yang, S.Y.; Hao, D.L.; Cong, Y.; Jin, M.; Su, Y.H. The rice OsAMT1;1 is a proton-independent feedback regulated ammonium transporter. Plant Cell Rep. 2015, 34, 321-330. [CrossRef] [PubMed]

68. Ranathunge, K.; El-kereamy, A.; Gidda, S.; Bi, Y.M.; Rothstein, S.J. AMT1;1 transgenic rice plants with enhanced NH+4 permeability show superiorgrowth and higher yield under optimal and suboptimalNH${ }_{4}^{+}$conditions. J. Exp. Bot. 2014, 65, 965-979. [CrossRef]

69. Li, T.; Liao, K.; Xu, X.; Gao, Y.; Wang, Z.; Zhu, X.; Xuan, Y.; Jia, B. Wheat Ammonium Transporter (AMT) Gene family: Diversity and possible role in host-pathogen interaction with stemrust. Front. Plant Sci. 2017, 8, 1637. [CrossRef]

70. Lee, S.; Marmagne, A.; Park, J.; Fabien, C.; Yim, Y.; Kim, S.; Kim, T.; Lim, P.; Masclaux-Daubresse, C.; Nam, H.G. Concurrent activation of OsAMT1;2 and OsGOGAT1 in rice leads to enhanced nitrogen use efficiency under nitrogen limitation. Plant J. 2020, 103, 7-20. [CrossRef]

71. Bao, A.; Liang, Z.; Zhao, Z.; Cai, H. Overexpressing of OsAMT1-3, a high affinity ammonium transporter gene, modifies rice growth and carbon-nitrogen metabolic status. Int. J. Mol. Sci. 2015, 16, 9037-9063. [CrossRef]

72. Alfatih, A.; Wu, J.; Zhang, Z.S.; Xia, J.Q.; Jan, S.U.; Yu, L.H.; Xiang, C.B. Rice NIN-LIKE PROTEIN 1 rapidly responds to nitrogen deficiency and improves yield and nitrogen use efficiency. J. Exp. Bot. 2020, 7, 6032-6042. [CrossRef] [PubMed]

73. Komarova, N.Y.; Thor, K.; Gubler, A.; Meier, S.; Dietrich, D.; Weichert, A.; Grotemeyer, M.S.; Tegeder, M.; Rentsch, D. AtPTR1 and AtPTR5 transport dipeptides in planta. Plant Physiol. 2008, 148, 856-869. [CrossRef]

74. Paungfoo-Lonhienne, C.; Lonhienne, T.G.A.; Rentsch, D.; Robinson, N.; Christie, M.; Webb, R.I. Plants can use protein as a nitrogen source without assistance from other organisms. Proc. Natl. Acad. Sci. USA 2008, 105, 4524-4529. [CrossRef] [PubMed]

75. Tegeder, M.; Masclaux-Daubresse, C. Source and sink mechanisms of nitrogen transport and use. New Phytol. 2018, 217, 35-53. [CrossRef]

76. Jones, D.L.; Healey, J.R.; Willett, V.B.; Farrar, J.F.; Hodge, A. Dissolved organic nitrogen uptake by plants—An important N uptake pathway? Soil. Biol. Biochem. 2005, 37, 413-423. [CrossRef]

77. Moran-Zuloaga, D.; Dippold, M.; Glaser, B.; Kuzyakov, Y. Organic nitrogen uptake by plants: Reevaluation by position-specific labeling of amino acids. Biogeochemistry 2015, 125, 359-374. [CrossRef]

78. Enggrob, K.L.; Jakobsen, C.M.; Pedersen, I.F.; Rasmussen, J. Newly depolymerized large organic N contributes directly to amino acid uptake in young maize plants. New Phytol. 2019, 224, 689-699. [CrossRef] [PubMed]

79. Xia, L.; Lam, S.K.; Yan, X.; Chen, D. How does recycling of livestock manure in agroecosystems affect crop productivity, reactive nitrogen losses, and soil carbon balance? Environ. Sci. Technol. 2017, 51, 7450-7457. [CrossRef]

80. Ji, Y.; Huang, W.; Wu, B.; Fang, Z.; Wang, X. The amino acid transporter AAP1 mediates growth and grain yield by regulating neutral amino acid uptake and reallocation in Oryza sativa. J. Exp. Bot. 2020, 71, 4763-4777. [CrossRef]

81. Lu, K.; Wu, B.; Wang, J.; Zhu, W.; Nie, H.; Qian, J.; Huang, W.; Fang, Z. Blocking amino acid transporter OsAAP3 improves grain yield by promoting outgrowth buds and increasing tiller number in rice. Plant Biotechnol. J. 2018, 16, 1710-1722. [CrossRef]

82. Wang, J.; Wu, B.; Lu, K.; Wei, Q.; Qian, J.; Chen, Y.; Fang, Z. The amino acid permease 5 (OsAAP5) regulates tiller number and grain yield in rice. Plant Physiol. 2019, 180, 1031-1045. [CrossRef]

83. Guo, N.; Hu, J.; Yan, M.; Qu, H.; Luo, L.; Tegeder, M.; Xu, G. Oryza sativa Lysine-Histidine-type Transporter 1 functions in root uptake and root-to-shoot allocation of amino acids in rice. Plant J. 2020, 103, 395-411. [CrossRef]

84. Lam, H.M.; Coschigano, K.T.; Oliveira, I.C.; Melo-Oliveira, R.; Coruzzi, G.M. The molecular-genetics of nitrogen assimilation into amino acids in higher plants. Annu. Rev. Plant Biol. 1996, 47, 569-593. [CrossRef] [PubMed] 
85. Tegeder, M.; Rentsch, D. Uptake and partitioning of amino acids and peptides. Mol. Plant 2010, 3, 997-1011. [CrossRef]

86. Xu, G.; Fan, X.; Miller, A.J. Plant nitrogen assimilation and use efficiency. Annu. Rev. Plant Biol. 2012, 63, 153-182. [CrossRef]

87. Liu, Q.; Chen, X.; Wu, K.; Fu, X. Nitrogen signaling and use efficiency in plants: What's new? Curr. Opin. Plant Biol. 2015, 27, 192-198. [CrossRef]

88. Beevers, L.; Hageman, R.H. Nitrate reduction in higher plants. Annu. Rev. Plant Physiol. 1969, 20, 495-522. [CrossRef]

89. Djennane, S.; Chauvin, J.E.; Meyer, C. Glasshouse behaviour of eight transgenic potato clones with a modified nitrate reductase expression under two fertilization regimes. J. Exp. Bot. 2002, 53, 1037-1045. [CrossRef]

90. Chamizo-Ampudia, A.; Sanz-Luque, E.; Llamas, A.; Galvan, A.; Fernandez, E. Nitrate reductase regulates plant nitric oxide homeostasis. Trends Plant Sci. 2017, 22, 163-174. [CrossRef] [PubMed]

91. Mauceri, A.; Bassolino, L.; Lupini, A.; Badeck, F.; Rizza, F.; Schiavi, M.; Toppino, L.; Abenavoli, M.R.; Rotino, G.L.; Sunseri, F. Genetic variation in eggplant for Nitrogen Use Efficiency under contrasting NO3-supply. J. Integr. Plant Biol. 2020, 62, 487-508. [CrossRef] [PubMed]

92. Yamaya, T.; Obara, M.; Nakajima, H.; Sasaki, S.; Hayakawa, T.; Sato, T. Genetic manipulation and quantitative-trait loci mapping for nitrogen recycling in rice. J. Exp. Bot. 2002, 53, 917-925. [CrossRef]

93. Yu, J.; Zhen, X.; Li, X.; Li, N.; Xu, F. Increased autophagy of rice can increase yield and nitrogen use efficiency (NUE). Front. Plant Sci. 2019, 10, 584. [CrossRef] [PubMed]

94. Zhen, X.; Xu, F.; Zhang, W.; Li, N.; Li, X. Overexpression of rice gene OsATG8b confers tolerance to nitrogen starvation and increases yield and nitrogen use efficiency (NUE) in Arabidopsis. PLoS ONE 2019, 14, e0223011. [CrossRef]

95. Fan, T.; Yang, W.; Zeng, X.; Xu, X.; Xu, Y.; Fan, X.; Zhang, M. A rice autophagy gene OsATG8b is involved in nitrogen remobilization and control of grain quality. Front. Plant Sci. 2020, 11, 588. [CrossRef] [PubMed]

96. Zhen, X.; Li, X.; Yu, J.; Xu, F. OsATG8c-mediated increased autophagy regulates the yield and nitrogen use efficiency in rice. Int. J. Mol. Sci. 2019, 20, 4956. [CrossRef]

97. Chichkova, S.; Arellano, J.; Vance, C.P.; Hernández, G. Transgenic tobacco plants that overexpress alfalfa NADH-glutamate synthase have higher carbon and nitrogen content. J. Exp. Bot. 2001, 52, 2079-2087. [CrossRef]

98. Brauer, E.K.; Rochon, A.; Bi, Y.M.; Bozzo, G.G.; Rothstein, S.J.; Shelp, B.J. Reappraisal of nitrogen use efficiency in rice overexpressing glutamine synthetase1. Physiol. Plant 2011, 141, 361-372. [CrossRef]

99. Lea, P.J.; Miflin, B.J. “Nitrogen assimilation and its relevance to crop improvement" in Nitrogen Metabolism in Plants in the Post-Genomic Era. Annu. Plant Rev. 2011, 42, 1-40.

100. Miflin, B.J.; Habash, D.Z. The role of glutamine synthetase and glutamate dehydrogenase in nitrogen assimilation and possibilities for improvement in the nitrogen utilization of crops. J. Exp. Bot. 2002, 53, 979-987. [CrossRef] [PubMed]

101. Chardon, F.; Noël, V.; Masclaux-Daubresse, C. Exploring NUE in crops and in Arabidopsis ideotypes to improve yield and seed quality. J. Exp. Bot. 2012, 63, 3401-3412. [CrossRef] [PubMed]

102. Cren, M.; Hirel, B. Glutamine synthetase in higher plants regulation of gene and protein expression from the organ to the cell. Plant Cell Physiol. 1999, 40, 1187-1193. [CrossRef]

103. Ferreira, S.; Moreira, E.; Amorim, I.; Santos, C.; Melo, P. Arabidopsis thaliana mutants devoid of chloroplast glutamine synthetase (GS2) have non-lethal phenotype under photorespiratory conditions. Plant Physiol. Biochem. 2019, 144, 365-374. [CrossRef]

104. Kusano, M.; Tabuchi, M.; Fukushima, A.; Funayama, K.; Diaz, C.; Kobayashi, M.; Saito, K. Metabolomics data reveal a crucial role of cytosolic glutamine synthetase 1;1 in coordinating metabolic balance in rice. Plant J. 2011, 66, 456-466. [CrossRef]

105. Sun, H.; Huang, Q.; Su, J. Highly effective expression of glutamine synthetase genes GS1 and GS2 in transgenic rice plants increases nitrogen-deficiency tolerance. Zhi Wu Sheng Li Yu Fen Zi Sheng Wu Xue Xue Bao 2005, 31, 492-498. [PubMed]

106. Migge, A.; Carrayol, E.; Hirel, B.; Becker, T.W. Leaf-specific overexpression of plastidic glutamine synthetase stimulates the growth of transgenic tobacco seedlings. Planta 2000, 210, 252-260. [CrossRef]

107. Fuentes, S.I.; Allen, D.J.; Ortiz-Lopez, A.; Hernández, G. Over-expression of cytosolic glutamine synthetase increases photosynthesis and growth at low nitrogen concentrations. J. Exp. Bot. 2001, 52, 1071-1081. [CrossRef]

108. Oliveira, I.C.; Brears, T.; Knight, T.J.; Clark, A.; Coruzzi, G.M. Overexpression of cytosolic glutamine synthetase. Relation to nitrogen, light, and photorespiration. Plant Physiol. 2002, 129, 1170-1180. [CrossRef]

109. Wang, Y.; Fu, B.; Pan, L.; Chen, L.; Fu, X.; Li, K. Overexpression of Arabidopsis Dof1, GS1 and GS2 enhanced nitrogen assimilation in transgenic tobacco grown under low-nitrogen conditions. Plant Mol. Biol. Rep. 2013, 31, 886-900. [CrossRef]

110. Zhu, C.; Fan, Q.; Wang, W.; Shen, C.; Meng, X.; Tang, Y.; Mei, B.; Xu, Z.; Song, R. Characterization of a glutamine synthetase gene DvGS2 from Dunaliella viridis and biochemical identification of DvGS2-transgenic Arabidopsis thaliana. Gene 2014, 536, 407-415. [CrossRef]

111. Urriola, J.; Rathore, K.S. Overexpression of a glutamine synthetase gene affects growth and development in sorghum. Transgenic Res. 2015, 24, 397-407. [CrossRef]

112. Martin, A.; Lee, J.; Kichey, T.; Gerentes, D.; Zivy, M.; Tatout, C.; Dubois, F.; Balliau, T.; Valot, B.; Davanture, M.; et al. Two cytosolic glutamine synthetase isoforms of maize are specifically involved in the control of grain production. Plant Cell 2006, 18, 3252-3274. [CrossRef]

113. Habash, D.Z.; Massiah, A.J.; Rong, H.L.; Wallsgrove, R.M.; Leigh, R.A. The role of cytosolic glutamine synthetase in wheat. Ann. App. Biol. 2001, 138, 83-89. [CrossRef] 
114. Hu, M.; Zhao, X.; Liu, Q.; Hong, X.; Zhang, W.; Zhang, Y.; Sun, L.; Li, H.; Tong, Y. Transgenic expression of plastidic glutamine synthetase increases nitrogen uptake and yield in wheat. Plant Biotechnol. J. 2018, 16, 1858-1867. [CrossRef] [PubMed]

115. Gao, Y.; de Bang, T.C.; Schjoerring, J.K. Cisgenic overexpression of cytosolic glutamine synthetase improves nitrogen utilization efficiency in barley and prevents grain protein decline under elevated CO2. Plant Biotechnol. J. 2019, 17, 1209-1221. [CrossRef]

116. Cai, H.; Zhou, Y.; Xiao, J.; Li, X.; Zhang, Q.; Lian, X. Overexpressed glutamine synthetase gene modifies nitrogen metabolism and abiotic stress responses in rice. Plant Cell Rep. 2009, 28, 527-537. [CrossRef]

117. Bao, A.; Zhao, Z.; Ding, G.; Shi, L.; Xu, F.; Cai, H. Accumulated expression level of cytosolic glutamine synthetase 1 gene (OsGS1;1 or OsGS1;2) alter plant development and the carbon-nitrogen metabolic status in rice. PLoS ONE 2014, 9, e95581. [CrossRef] [PubMed]

118. Thomsen, H.C.; Eriksson, D.; Møller, I.S.; Schjoerring, J.K. Cytosolic glutamine synthetase: A target for improvement of crop nitrogen use efficiency? Trends Plant Sci. 2014, 19, 656-663. [CrossRef]

119. Garnett, T.; Plett, D.; Heuer, S.; Okamoto, M. Genetic approaches to enhancing nitrogen-use efficiency (NUE) in cereals: Challenges and future directions. Funct. Plant Biol. 2015, 42, 921-941. [CrossRef] [PubMed]

120. Sweetlove, L.J.; Nielsen, J.; Fernie, A.R. Engineering central metabolism-a grand challenge for plant biologists. Plant J. 2017, 90, 749-763. [CrossRef]

121. Luo, L.; Wang, H.X.; Liu, X.H.; Hu, J.Q.; Zhu, X.L.; Pan, S.; Qin, R.Y.; Wang, Y.F.; Zhao, P.P.; Fan, X.R.; et al. Strigolactones affect the translocation of nitrogen in rice. Plant Sci. 2018, 270, 190-197. [CrossRef]

122. Benjamins, R.; Scheres, B. Auxin: The Looping Star in Plant Development. Annu. Rev. Plant Biol. 2008, 59, 443-465. [CrossRef]

123. Zhang, S.Y.; Zhu, L.M.; Shen, C.B.; Ji, Z.; Zhang, H.P.; Zhang, T.; Li, Y.; Yu, J.P.; Yang, N.; He, Y.B.; et al. Natural allelic variation in a modulator of auxin homeostasis improves grain yield and nitrogen use efficiency in rice. Plant Cell 2021, 5, 566-580. [CrossRef]

124. Hou, M.; Luo, F.; Wu, D.; Zhang, X.; Lou, M.; Shen, D.; Yan, M.; Mao, C.; Fan, X.; Xu, G.; et al. OsPIN9, an auxin efflux carrier, is required for the regulation of rice tiller bud outgrowth by ammonium. New Phytol. 2021, 229, 935-949. [CrossRef]

125. Itoh, H.; Ueguchi-Tanaka, M.; Sato, Y.; Matsuoka, A.M. The gibberellin signaling pathway is regulated by the appearance and disappearance of SLENDER RICE1 in nuclei. Plant Cell 2002, 14, 57-70. [CrossRef] [PubMed]

126. Asano, K.; Yamasaki, M.; Takuno, S.; Miura, K.; Katagiri, S.; Ito, T.; Doi, K.; Wu, J.; Ebana, K.; Matsumoto, T.; et al. Artificial selection for a green revolution gene during japonica rice domestication. Proc. Natl. Acad. Sci. USA 2011, 108, 11034-11039. [CrossRef] [PubMed]

127. Li, S.; Tian, Y.; Wu, K.; Ye, Y.; Yu, J.; Zhang, J.; Liu, Q.; Hu, M.; Li, H.; Tong, Y.; et al. Modulating plant growth-metabolism coordination for sustainable agriculture. Nature 2018, 560, 595-600. [CrossRef] [PubMed]

128. Hedden, P. The genes of the Green Revolution. Trends Genet. 2003, 19, 5-9. [CrossRef]

129. Wu, K.; Wang, S.S.; Song, W.Z.; Zhang, J.Q.; Wang, Y.; Liu, Q.; Yu, J.P.; Ye, Y.F.; Li, S.; Chen, J.F.; et al. Enhanced sustainable green revolution yield via nitrogen-responsive chromatin modulation in rice. Science 2020, 367, eaaz2046. [CrossRef] [PubMed]

130. Wu, X.Y.; Ding, C.H.; Baerson, S.R.; Lian, F.Z.; Lin, X.H.; Zhang, L.Q.; Wu, C.F.; Hwang, S.Y.; Zeng, R.S.; Song, Y.Y. The roles of jasmonate signalling in nitrogen uptake and allocation in rice (Oryza sativa L.). Plant Cell Environ. 2019, 42, 659-672. [CrossRef]

131. Wang, C.G.; Wang, G.K.; Gao, Y.; Lu, G.H.; Habben, J.E.; Mao, G.F.; Chen, G.W.; Wang, J.T.; Yang, F.; Zhao, X.Q.; et al. A cytokinin-activation enzyme-like gene improves grain yield under various field conditions in rice. Plant Mol. Biol. 2020, 102, 373-388. [CrossRef]

132. Xu, G.H.; Takahashi, H. Improving nitrogen use efficiency: From cells to plant systems. J. Exp. Bot. 2020, 71, 4359-4364. [CrossRef]

133. Qin, P.; Lu, H.; Du, H.; Wang, H.; Chen, W.; Chen, Z.; He, Q.; Ou, S.; Zhang, H.; Li, X.; et al. Pangenome analysis of 33 genetically diverse rice accessions reveals hidden genomic variations. Cell 2021, 184, 3542-3558.e16. [CrossRef]

134. Fan, X.R.; Naz, M.; Fan, X.R.; Xuan, W.; Miller, A.J.; Xu, G.H. Plant nitrate transporters: From gene function to application. J. Exp. Bot. 2020, 68, 2463-2475. [CrossRef] [PubMed]

135. Abenavoli, M.R.; Longo, C.; Lupini, A.; Miller, A.J.; Araniti, F.; Mercati, F.; Princi, M.P.; Sunseri, F. Phenotyping two tomato genotypes with different nitrogen use efficiency. Plant Physiol. Biochem. 2016, 107, 21-32. [CrossRef]

136. Naz, M.; Luo, B.; Guo, X.; Li, B.; Chen, J.; Fan, X. Overexpression of Nitrate Transporter OsNRT2.1 Enhances Nitrate-Dependent Root Elongation. Genes 2019, 10, 290. [CrossRef] 